Sains Malaysiana 47(6)(2018): 1221-1226

http://dx.doi.org/10.17576/jsm-2018-4706-17

\title{
Effects of Durian Fruit on Blood Pressure of Spontaneously Hypertensive Rats
}

(Kesan Buah Durian ke Atas Tekanan Darah Tikus Hipertensi Spontan)

\author{
MALINA JASAMAI, NURUl HANIS SAMSUDIN, NORAZRINA AZMI \& ENDANG KUMOLOSASI*
}

ABSTRACT

Durian or scientifically known as Durio zibethinus is one of the most well-known seasonal fruits in the Southeast Asia region. However, its safe consumption in individuals with hypertension is still controversial. This study was conducted to investigate the effect of durian on blood pressure of spontaneously hypertensive rat model. Four groups of rats $(\mathrm{n}=5)$ were fed with either a low dose durian (26 g/kg), a high dose durian (52 g/kg), sugar solution $(8 \mathrm{~mL} / \mathrm{kg})$ which has similar sugar composition in the durian as placebo control, and distilled water as vehicle control ( $8 \mathrm{~mL} / \mathrm{kg})$ for $14 \mathrm{days}$. The durian doses for rats were obtained by converting from human doses. Baseline reading of blood pressure and heart rate were recorded before the first oral administration of durian. The blood pressure and heart rate were also measured $1 \mathrm{~h}$ after the durian oral administration on day 1, 3, 7 and 14 of the experiment. In conclusion, durian fruit possessed an acute effect on the blood pressure of hypertensive rats but heart rate was unaffected. High dose administration of durian led to significant elevation of blood pressure after $1 \mathrm{~h}$ of consumption. Meanwhile, low dose of durian (26 g/kg) caused an insignificant reduction in systolic and diastolic blood pressure. Tolerance to the durian fruit was observed after three to seven days of the oral administration and low dose consumption of durian fruit was safe in the hypertensive rat.

Keywords: Blood pressure; durian; heart rate; hypertension; spontaneously hypertensive rats

\section{ABSTRAK}

Durian atau nama saintifiknya Durio zibethinus adalah sejenis buah bermusim yang paling terkenal di rantau Asia Tenggara. Walau bagaimanapun, penggunaannya yang selamat pada individu berpenyakit hipertensi masih kontroversi. Kajian ini dijalankan untuk mengkaji kesan durian terhadap tekanan darah pada model tikus berhipertensi spontan. Empat kumpulan tikus $(\mathrm{n}=5)$ diberi sama ada dos durian yang rendah (26 g/kg), dos durian tinggi (52 $\mathrm{g} / \mathrm{kg})$, larutan gula $(8 \mathrm{~mL} / \mathrm{kg}$ ) yang menyamai komposisi gula dalam durian sebagai kawalan plasebo atau air minuman sebagai kawalan negatif $(8 \mathrm{~mL} / \mathrm{kg}$ ) selama 14 hari. Dos durian untuk tikus diperoleh melalui pertukaran daripada dos manusia. Bacaan asas tekanan darah dan kadar denyutan jantung direkodkan sebelum pemberian oral dos pertama durian. Tekanan darah dan kadar denyutan jantung juga diukur satu jam selepas pemberian oral dos durian pada hari ke 1, 3, 7 dan 14 eksperimen. Kesimpulannya, buah durian mempunyai kesan akut pada tekanan darah tikus berhipertensi tetapi kadar denyutan jantung tidak terjejas. Pengambilan dos durian yang tinggi menunjukkan peningkatan ketara tekanan darah selepas satu jam. Sementara itu, pengambilan dos durian yang rendah $(26 \mathrm{~g} / \mathrm{kg})$ menyebabkan penurunan tekanan darah sistolik dan diastolik yang tidak ketara. Toleransi terhadap buah durian diperhatikan selepas tiga hingga tujuh hari pemberian oral dan pengambilan dos buah durian yang rendah adalah selamat pada tikus berhipertensi.

Kata kunci: Durian; hipertensi; kadar denyutan jantung; tekanan darah; tikus berhipertensi spontan

\section{INTRODUCTION}

Durian fruit or Durio zibethinus Murray is a one of the famous seasonal fruits in the Southeast Asia. It is a member of Bombacaceae family and widely known as the 'king of fruits'. Besides, durian fruit is rich in nutritional values such as antioxidants (vitamin $\mathrm{E}$ and beta-carotene), minerals (potassium, magnesium, calcium and sodium), trace elements (iron, zinc, copper and manganese), sulphur compounds and sugars (sucrose, fructose and glucose) (Voon et al. 2007).

In addition, durian plant is also used traditionally to treat diseases such as fever, jaundice and infertility (Ansari 2016; Sah et al.2014). However, despite of its nutraceutical and medicinal values, durian is believed to be a 'heaty' food (Ariff \& Beng 2006). Durian fruit is also avoided by pregnant women in Indonesia as they believe that its consumption could lead to miscarriage (Hartini et al. 2005). Moreover, people with hypertension are concerned that eating durian might increase their blood pressure (BP) (Ariff \& Beng 2006).

There is a limited study carried out about the relationship of durian on BP. A previous study on normal Sprague Dawley rats suggested that no significant differences in BP of normal rats after being fed with durian (Chua et al. 2008). Recently, research carried out by Kumolosasi et al. (2016) reported that there was also no significant increase in BP in healthy human subjects after durian consumption, but significant increase in heart rate 
was observed. To the best of authors' knowledge, the effect of durian on hypertensive subjects has not been studied. This study was carried out to investigate the effect of durian fruit on BP and heart rate of spontaneously hypertensive rats (SHR).

\section{Materials AND Methods}

\section{APPARATUS}

CODA $_{\mathrm{TM}}$ tail-cuff equipment (Kent Scientific, USA), weighing machine (A \& D, Japan), refrigerator (Sharp), $3 \mathrm{~mL}$ syringe (Terumo), $5 \mathrm{~mL}$ syringe (Terumo), amber bottles, filter, oral gavage, rats' cages, water bottles, tissue paper, masks and gloves.

\section{FOOD MATERIALS}

Durian flesh (clone D24) was purchased from a local market in Kuala Lumpur, Malaysia, distilled water, glucose powder, crystalline fructose and sucrose.

\section{ANIMALS}

Female SHR with weight ranging from 150 - $200 \mathrm{~g}$ were purchased from the Animal Experimental Unit (AEU) of University Malaya. The rats were kept randomly in different plastic cages with three rats in each cage. Then, the rats were adapted at a well-ventilated animal laboratory under $26 \pm 1^{\circ} \mathrm{C}$ with standard 12-h/12-h light/ dark cycle for at least one week before the experiment was carried out. They were fed with standard pellet diet and water ad libitum. The animals were maintained under standard conditions and procedures were approved by the UKM Animal Ethics Committee with an approval number FF/2016/ENDANG/18-MAY/753-MAY-2016-JAN-2017.

\section{PREPARATION OF THE TEST SAMPLES AND CONTROLS}

Test samples consists of two different doses of durian flesh (26 g/ $\mathrm{kg}$ body weight) for low dose and $(52 \mathrm{~g} / \mathrm{kg}$ body weight) for high dose. The durian flesh was separated from their seeds and passed through a tea strainer to remove the fibre. The texture was soft enough to allow oral administration using a size 15 oral gavage needle. Both low and high doses of the durian were based on conversion from human dose of previous study carried out by Kumolosasi et al. (2016) to the rat dose. The dose conversion was calculated according to Laurence and Bacharach (1964). Placebo control used in this experiment was sugar solution consisting of sucrose, fructose and glucose at a ratio of (8 $: 1: 1)$, respectively, to match the sugar composition in $250 \mathrm{~g}$ durian flesh while the vehicle control group of rats received only distilled water.

\section{BP AND HEART RATE MEASUREMENT}

Preliminary study was carried out to determine the optimum time for BP measurement after oral administration of durian. Three rats per group were used and fed with high dose of durian $(52 \mathrm{~g} / \mathrm{kg})$. Following the oral administration, the BP of each rat was recorded at time intervals of 0.5 , $1,2,3$ and $4 \mathrm{~h}$. The peak BP was found at $1 \mathrm{~h}$ after durian administration.

The actual study was carried out using five rats per group. BP of the rats were recorded using CODA Non-Invasive Blood Pressure System prior to oral administration of durian. The measurement provided the baseline parameter for the BP of the rats. The BP measurements were then repeated after $1 \mathrm{~h}$ (peak BP from the preliminary study) of the oral administration on day 1 , day 3 , day 7 and day 14 of the experiment. Five stable readings were recorded. The average values of the heart rate, SBP and DBP were calculated.

\section{STATISTICAL ANALYSIS}

The parameters measured in this experiment were heart rate, systolic and diastolic blood pressure before and after oral administration of durian. Data were analyzed using PRISM software version 5. The differences between the groups were investigated using a one-way analysis of variance (ANOVA), followed by Tukey post hoc test. The differences were considered significant if $p<0.05$.

\section{RESULT AND DISCUSSION}

Figure 1 shows the mean systolic blood pressure (SBP), diastolic blood pressure (DBP) and heart rate (HR) of SHR within $4 \mathrm{~h}$ after oral administration of $52 \mathrm{~g} / \mathrm{kg}$ durian. The mean SBP and DBP increased significantly $(p<0.05)$ after $1 \mathrm{~h}$ of the durian administration. After that, the mean SBP and DBP readings decreased slowly to their baseline levels. It was observed that the mean heart rate increased after the oral administration and reached its peak after one hour, but the increment is not significant. The mean heart rate also decreased slowly and reached its baseline level within $4 \mathrm{~h}$ post oral administration of durian.

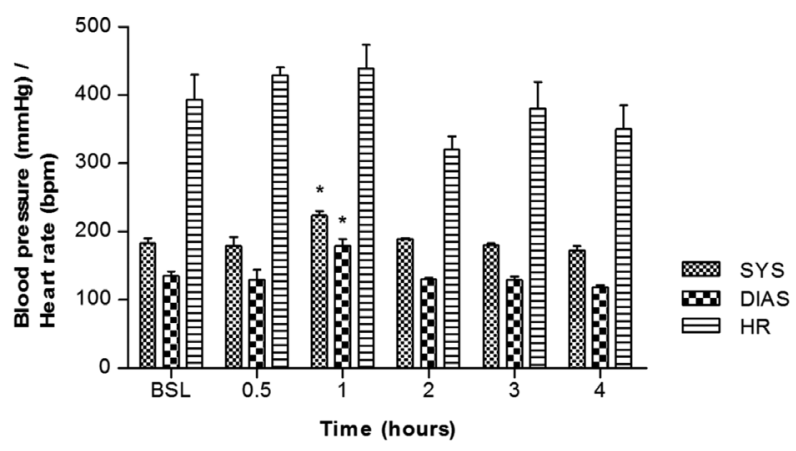

Value expressed as mean \pm standard error mean (SEM); $n=3$; BSL, Baseline reading (before durian administration); SYS, Systolic blood pressure; DIAS, Diastolic blood pressure; HR, Heart rate. *Statistically significant difference $(p<0.05)$ compared with BSL

FIGURE 1. Blood pressure $(\mathrm{mmHg})$ and heart rate $(\mathrm{bpm})$ of SHR within $4 \mathrm{~h}$ after oral administration of $52 \mathrm{~g} / \mathrm{kg}$ durian 
The preliminary study indicated that administration of $52 \mathrm{~g} / \mathrm{kg}$ durian fruit possess an effect on the BP of SHRs, where it can further increase the systolic and diastolic BP. In SHR, the elevated BP is initially caused by an increased in central sympathetic outflow, followed by enhanced total peripheral resistance (TPR) with a normal cardiac output (CO) and decreased in permeability of glomerular membranes (Badyal et al. 2003). Thus, durian may cause rise in the $\mathrm{BP}$ by altering those factors, but this mechanism of action has not been investigated.

The peak time of the effect observed was $1 \mathrm{~h}$ and it was suggested that the concentration of the bioactive compounds in durian fruit that cause the SBP and DBP to rise was the highest in the rats' blood after $1 \mathrm{~h}$ of durian consumption.

Subsequently, the mean SBP and DBP readings decreased slowly to their baseline level after $1 \mathrm{~h}$. However, different findings for the heart rate were observed, in which the increment after $1 \mathrm{~h}$ of feeding with $52 \mathrm{~g} / \mathrm{kg}$ durian was not significant. This finding differs from previous study that reported the consumption of high dose durian (500 g) by healthy human subject lead to a significant increase in heart rate after 0.5 to $2 \mathrm{~h}$ (Kumolosasi et al. 2016). The finding in the rats suggests that the consumption of high dose durian by SHR only affected their SBP and DBP, but not their heart rate.

Previous research reported that $\mathrm{BP}$ and heart rate are controlled by one central mechanism, most likely the suprachiasmatic nucleus in the hypothalamus, but independent control of those parameter are also possible (Janssen et al. 1994; Saleh \& Winget 1977; Sano et al. 1995). In addition, blood pressure is the product of the cardiac output and total peripheral resistance, thus any alteration to the BP can be done by modifying one of those factors (Opie \& Kaplan 2012).

\section{EFFECT OF DIFFERENT DOSES OF DURIAN ON BLOOD PRESSURE}

Figure 2(A) and 2(B) shows the effect of different doses of durian on SBP throughout 14 days of the study. Figure 2(A) shows that after the first dose of oral administration, the SBP of the low dose group decreased compared to the vehicle control group, but the reduction is not significant. The SBP of high dose group increased compared to the vehicle control group. However, the increment was also not significant. Interestingly, the mean SBP of the low dose and high dose groups was significant difference $(p<0.01, n=5)$ at day1 and with $p$-value $<0.05, n=5$ at day 3 , respectively. Towards the 14 th day of the oral administration, high dose, low dose and placebo control group showed an increase in mean SBP, but the values were not significant compared to vehicle control group. Figure 2(B) illustrates the mean change in SBP. The high dose group possess positive mean change (increase) in the SBP, meanwhile the other three groups showed negative change (decrease). On day 1, the change in SBP of high dose group was significant compared to vehicle control $(p<0.05, n=5)$, placebo control $(p<0.01, n=5)$ and low dose $(p<0.01, n=5)$ groups, respectively. Then on the day 3 to day 14 no changes were significant.

The effect of different doses of durian on the DBP is illustrated in Figure 3(A) and 3(B). Figure 3(A) shows that on day 1 , the high dose group of durian $(52 \mathrm{~g} / \mathrm{kg})$ produced a significant increase in DBP compared to placebo control group and low dose group with $(p<0.05, n=5)$ for both. The change of DBP of high dose group on day 1 was significant higher $(p<0.01, n=5)$ compared with VC, $(p<0.01, n=5)$ compared with LD and $(p<0.01, n=5)$ compared with PC, respectively. The profile was similar with SBP where on the day 3 to day 14 no more significant changes were observed (Figure 3(B)).
A

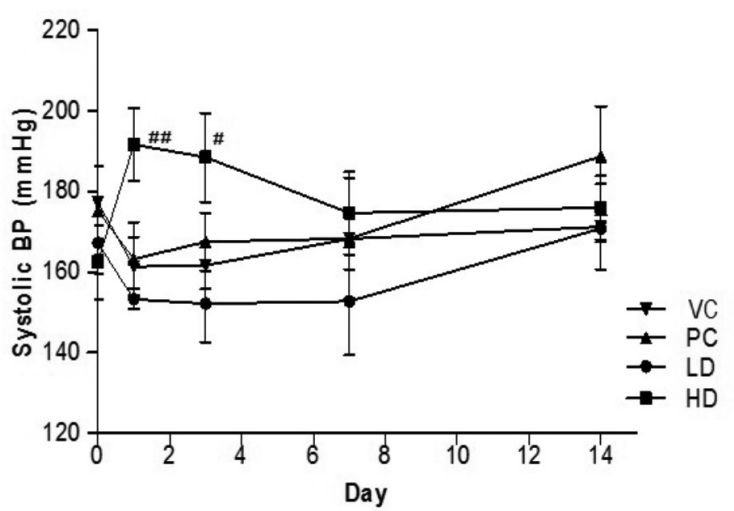

B

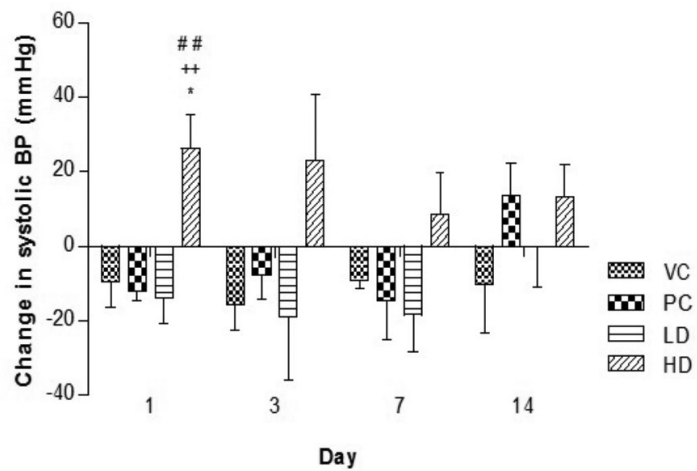

Value expressed as mean \pm standard error mean (SEM); $n=5$; VC, Vehicle control; PC, Placebo control; LD, Low dose (26 g/kg); HD, High dose (52 g/ $\mathrm{kg})$. *Statistically significant difference $(p<0.05)$ when compared with VC. $++(p<0.01)$ compared with PC. \# Statistically significant difference $(p<0.05)$ and \#\# $(p<0.01)$ compared with LD, respectively

FIGURE 2. (A) Systolic blood pressure of SHR throughout 14 days of experiment and (B) Change in systolic blood pressure of SHR throughout 14 days of experiment 
A

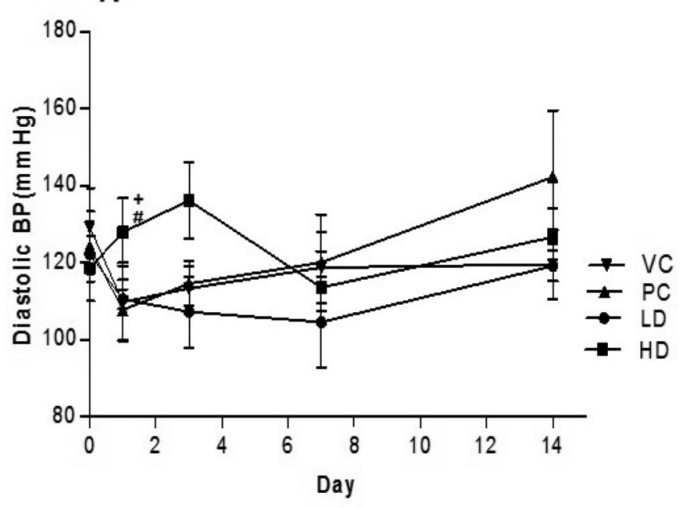

B

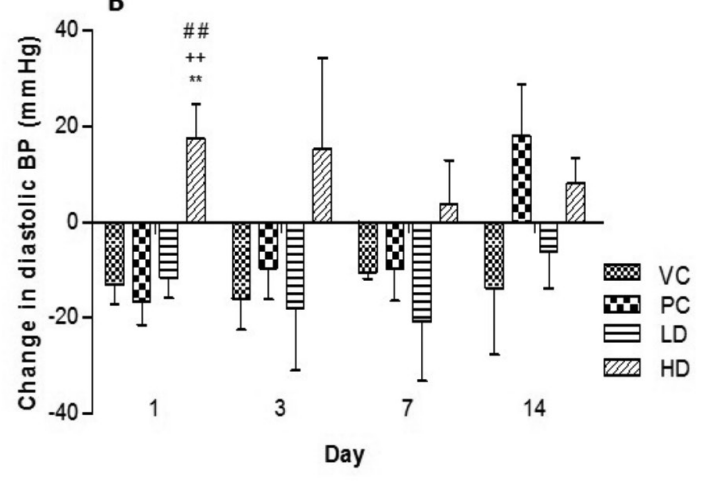

Value expressed as mean \pm standard error mean (SEM); $n=5$. LD, Low dose $(26 \mathrm{~g} / \mathrm{kg}) ; \mathrm{HD}$, High dose $(52 \mathrm{~g} / \mathrm{kg}) ; \mathrm{VC}$, Vehicle control; PC, Placebo control. ** Statistically significant difference $(p<0.01)$ compared with VC. \#Statistically significant difference $(p<0.05)$ and $\# \#(p<0.01)$ when compared with LD, respectively. $+(p<0.05)$ and $++(p<0.01)$ when compared with PC, respectively

FIGURE 3. (A) Diastolic blood pressure of SHR throughout 14 days of experiment and (B) Change in diastolic blood pressure of SHR throughout 14 days of experiment

Different doses of durian had shown to affect BP differently. The opposite effect on the SBP might be related to the different concentration of bioactive compounds that caused alteration in the mean SBP. This finding suggests that the low dose of durian $(26 \mathrm{~g} / \mathrm{kg})$ contain insufficient amount of bioactive compounds that can lead to mean SBP elevation.

The significant difference in mean SBP between the low dose and high dose group of durian only persisted on day 1 until the third day of the experiment. Meanwhile, the mean DBP between the low and high dose group showed a significant difference only after the first day of oral administration. This suggests that durian fruit showed an acute effect on the SBP and DBP of SHRs. Repeated doses of durian showed reduced response on the SBP may due to tolerance. Tolerance can be developed by different mechanism including the change in receptor, physiological adaptation or increased in metabolic degradation of the drugs or bioactive compounds (Rang et al. 2011).

The high dose group showed a considerably persistent elevation in SBP and DBP throughout the period of study. Even though the high dose group are significant only at day 1 and 3 for SBP and at day 1 for DBP then followed by insignificant difference compared to vehicle control, this finding suggests that durian need to be taken in considerable amount by hypertensive subjects as it can cause an increase in SBP and DBP which might increase the risk of other cardiovascular events (Sokolow et al. 1966). Another study done by Chua et al. (2008) also reported that the blood pressure of Sprague Dawley rats within $5 \mathrm{~h}$ interval after oral administration of $16 \mathrm{~g} / \mathrm{kg}$ durian shows no significant difference from the baseline level. However, the doses used in their study is much lower compared to those in this study which were 26 and $52 \mathrm{~g} / \mathrm{kg}$, moreover the rats used in their study were not hypertensive rats which might be the reason to the differences in our findings.
Previous study carried out by Kumolosasi et al. (2016) reported that there was no alteration in SBP and DBP in healthy human after the consumption of low or high dose of durian. However, in this study, there is a persistent alteration in the SBP and DBP in SHRs throughout the experiment. BP measurement of normal rats also showed insignificant difference within $5 \mathrm{~h}$ post oral administration of $16 \mathrm{~g} / \mathrm{kg}$ durian (Chua et al. 2008). This suggests that durian fruit affected the BP of healthy humans or normal rats and hypertensive rats (pathological condition) differently.

Rats in the placebo control group received sugar solution with similar sugar composition with the $26 \mathrm{~g} /$ $\mathrm{kg}$ durian (Voon et al. 2007). Since the placebo control contained the same amount of sugar as in the low dose of durian, this suggests that the increment in mean SBP by both groups after seventh day of oral administration was caused by the repeated consumption of sugar-containing food (sucrose, fructose and glucose). This is consistent with the result from previous research that reported fructose may increase BP and promote the accumulation of visceral adiposity, dyslipidemia and ectopic fat deposition because of increased hepatic de novo lipogenesis (Stanhope et al. 2009). Besides, diet which contained high amount of sugar might have triggered a rise in BP which is about twice as seen in a high salt diet (Dinicolantonio \& O'keefe 2016).

\section{EFFECT OF DIFFERENT DOSES OF DURIAN ON HEART RATE (HR)}

Figure 4(A) and 4(B) presents the overall effect of both doses of durian groups on heart rate. Figure 4(A) shows that the placebo control and high dose groups contributed to the rise in heart rate while low dose and vehicle control groups showed reducing effect in heart rate after the first administration. However, all of the values are statistically insignificant. Meanwhile, there 
A

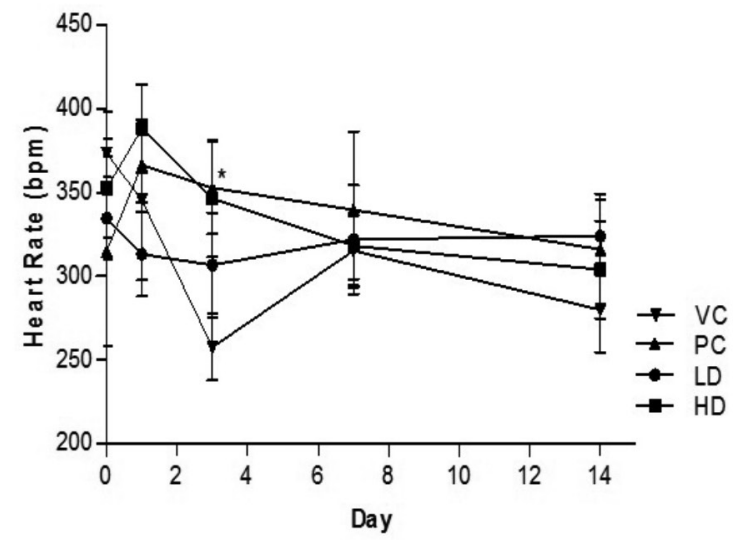

B

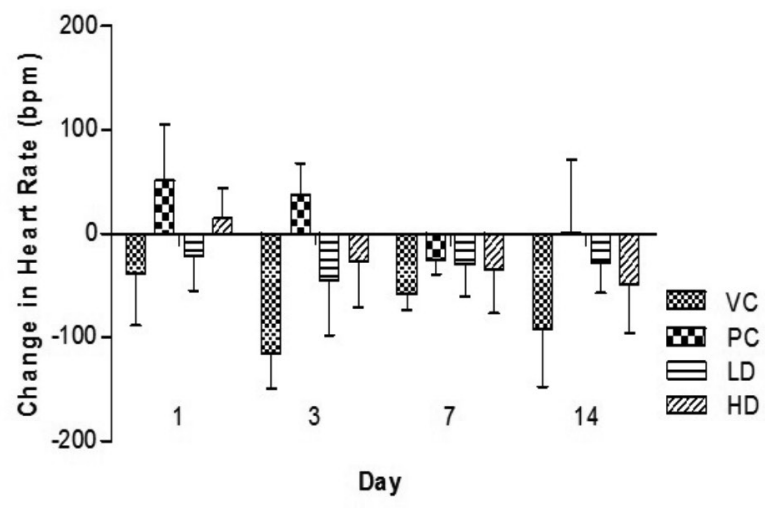

Value expressed as mean \pm standard error mean (SEM); $n=5$. LD, Low dose (26 g/kg); HD, High dose (52 g/kg); VC, Vehicle control; PC, Placebo control . *Statistically significant difference $(p<0.05)$ when compared with VC

FIGURE 4. (A) Heart rate of SHR throughout 14 days of experiment and (B) Change in heart rate of SHR throughout 14 days of experiment

was a significant difference between placebo control group and vehicle control group on the third day of the experiment $(p<0.05, n=5)$. As shown in Figure 4(B), the placebo control and high dose groups showed an increase in the mean HR on day 1 but the low dose group showed reduction in HR. Nonetheless, those differences were not significant when compared to vehicle control. The mean HR for the placebo control on day 3 was shown to increase following the oral administration. At the same time, the mean HR of both low and high doses of durian showed reduction but no significant difference was observed. The pattern of the mean change of HR was reduced on day 7 onwards.

Dinicolantonio and O'Keefe (2016) reported that a high-sugar diet seems to increase heart rate, promote insulin resistance and obesity. In this study, SHRs receiving sugar solution also possess an increment in heart rate at 1 $\mathrm{h}$ post oral administration. Though the increment is not significant, the increment pattern also showed in another study that reported after $0.5-2 \mathrm{~h}$ of oral administration of sugar solution (sucrose, fructose and glucose), there was a significant increase in HR shown by healthy human subjects (Kumolosasi et al. 2016).

\section{CONCLUSION}

Durian fruit possess an acute effect on the BP of the hypertensive rats by altering the SBP and DBP but heart rate was unaffected. High dose administration of durian $(52 \mathrm{~g} / \mathrm{kg})$ led to a significant elevation of SBP and DBP after $1 \mathrm{~h}$ on the first day of consumption. Meanwhile, low dose administration of durian $(26 \mathrm{~g} / \mathrm{kg})$ appeared to show insignificant reduction in SBP and DBP. Tolerance to the durian fruit was developed after three to seven days of oral administration. The low dose consumption of durian fruit did not affect BP and HR, however the caution is necessary if taking a high dose of durian in hypertensive subjects.

\section{ACKNOWLEDGEMENTS}

This present study was performed at the Pharmacology Laboratory of Faculty of Pharmacy, Universiti Kebangsaan Malaysia.

\section{REFERENCES}

Ansari, R.M. 2016.Potential use of durian fruit (Durio Zibenthinus Linn) as an adjunct to treat infertility in polycystic ovarian syndrome. Journal of Integrative Medicine 14(1): 22-28.

Ariff, K.M. \& Beng, K.S. 2006. Cultural health beliefs in a rural family practice: A malaysian perspective. Australian Journal of Rural Health 14(1): 2-8.

Badyal, D., Lata, H. \& Dadhich, A. 2003. Animal models of hypertension and effect of drugs. Indian Journal of Pharmacology 35(6): 349-362.

Chua, Y., Nurhaslina, H. \& Gan, S. 2008. Hyperthermic effects of Durio Zibethinus and its interaction with paracetamol. Methods and Findings in Experimental and Clinical Pharmacology 30(10): 739-743.

Dinicolantonio, J.J. \& O'keefe, J.H. 2016. Hypertension due to toxic white crystals in the diet: Should we blame salt or sugar?. Progress in Cardiovascular Diseases 59(3): 219-225.

Hartini, T.N.S., Padmawati, R.S., Lindholm, L., Surjono, A. \& Winkvist, A. 2005. The importance of eating rice: Changing food habits among pregnant indonesian women during the economic crisis. Social Science \& Medicine 61(1): 199-210.

Janssen, B., Tyssen, C., Duindam, H. \& Rietveld, W. 1994. Suprachiasmatic lesions eliminate $24-\mathrm{H}$ blood pressure variability in rats. Physiology \& Behavior 55(2): 307-311.

Kumolosasi, E., Siew Gyn, T., Mansor, A.H., Makmor Bakry, M., Azmi, N. \& Jasamai, M. 2016. Effects of durian intake on blood pressure and heart rate in healthy individuals. International Journal of Food Properties 19: 1483-1488.

Laurence, D.R. \& Bacharach, A.L. 1964. Evaluation of drug activities: Pharmacometrics. Journal of Pharmaceutical Sciences 54(7): 1080.

Opie, L.H. \& Kaplan, N. M. 2012. Antihypertensive drugs. In Drugs for the Heart, edited by Opie, L.H. \& Gersh, B.J. Cape Town: Elsevier Health Sciences. pp. 198-234. 
Rang, H.P., Dale, M.M., Ritter, J.M., Flower, J.R. \& Henderson, G. 2011. How drugs act: General principles. In Rang and Dale's Pharmacology, 7th ed., edited by Hyde, M., Mortimer, A. \& Lowson, K. New York: Elsevier/Churchill Livingstone. pp. 6-19.

Sah, B.P., Pathak, T., Sankar, S. \& Suresh, B. 2014. Phytochemical investigations on the fruits of Durio zibenthinus linn. for antimicrobial activity. International Journal of Pharma Science and Researches 5(12): 878-891.

Saleh, M.A. \& Winget, C.M. 1977. Effect of suprachiasmatic lesions on diurnal heart rate rhythm in the rat. Physiology \& Behavior 19(4): 561-564.

Sano, H., Hayashi, H., Makino, M., Takezawa, H., Hirai, M., Saito, H. \& Ebihara, S. 1995. Effects of suprachiasmatic lesions on circadian rhythms of blood pressure, heart rate and locomotor activity in the rat. Japanese Circulation Journal 59(8): 565-573.

Sokolow, M., Werdegar, D., Kain, H.K. \& Hinman, A.T. 1966. Relationship between level of blood pressure measured casually and by portable recorders and severity of complications in essential hypertension. Circulation 34(2): 279-298.

Stanhope, K.L., Schwarz, J.M., Keim, N.L., Griffen, S.C., Bremer, A.A., Graham, J.L., Hatcher, B., Cox, C.L., Dyachenko, A. \& Zhang, W. 2009. Consuming fructose-sweetened, not glucose-sweetened, beverages increases visceral adiposity and lipids and decreases insulin sensitivity in overweight/ obese humans. The Journal of Clinical Investigation 119(5): 1322-1334.
Voon, Y.Y., Abdul Hamid, N.S., Rusul, G., Osman, A. \& Quek, S.Y. 2007. Characterisation of Malaysian durian (Durio zibethinus murr.) cultivars: Relationship of physicochemical and flavour properties with sensory properties. Food Chemistry 103(4): 1217-1227.

Drug and Herbal Research Centre

Faculty of Pharmacy

Universiti Kebangsaan Malaysia

Jalan Raja Muda Abdul Aziz

50300 Kuala Lumpur, Federal Territory

Malaysia

*Corresponding author; email: e_kumolosasi@ukm.edu.my

Received: 11 October 2017

Accepted: 6 February 2018 